\title{
Analysis of Mixtures of Olefin Hydrocarbons Produced by Codimerization of Butenes ${ }^{1}$
}

\author{
Augustus R. Glasgow, Jr.
}

\begin{abstract}
This paper describes the analysis, with respect to individual components, of three mixtures of olefin hydrocarbons. These were produced by the combination to form dimers of mixed butenes in a tubular type reactor with phosphoric acid as catalyst. Products of such reactions are called "codimers" and the process "codimerization". The analyses were made by utilizing distillations performed at high efficiency with high reflux ratio, with accurately measured values of the boiling point and refractive index of the fractions of distillate, and with separation by adsorption of the paraffin portion of selected distillate. In the case of one codimer, use was made of the previous analysis of the corresponding mixture of paraffins produced by hydrogenation of the codimer.
\end{abstract}

\section{Introduction}

As part of its war research program, the American Petroleum Institute Research Project 6 at the National Bureau of Standards was called upon, by the Technical Advisory Committee of the Petroleum Industry War Council and the National Advisory Committee for Aeronautics, to determine the components of mixtures of hydrocarbons produced by commercial processes important in the preparation of high-octane aviation fuels. Included in the program were three samples of mixtures of olefin hydrocarbons produced by the codimerization of butenes and, in addition, a sample of the product obtained by hydrogenation of one of the above mixtures. Since, in the petroleum industry, a mixture of olefins such as that produced by the combination of butenes is called "a codimer", and the product formed by hydrogenation of the codimer is called "hydrocodimer", these terms will be used in the text.

The analysis of various mixtures of alkylates ${ }^{2}$ and hydrocodimers, including the hydrocodimer referred to in this paper, by analytical distillation and the measurement of physical properties of the distillates was previously described. ${ }^{3}$ This report gives the method and results of the analyses of the mixtures of monoolefin hydrocarbons that comprise the codimers. The analysis of a mixture of olefins is more complicated than the analysis of a mixture of the corresponding paraffin hydrocarbons because of (a) the presence of many more close-boiling isomers, (b) the lack of accurate data on the physical properties of all the pure components, and (c) the greater susceptibility of the olefins to oxidation.

\section{Material Analyzed}

The material analyzed was the product of the codimerization of material, which was mainly a mixture

\footnotetext{
1 This investigation was performed as part of the work of the A merican Petroleum Institute Research Project 6 at the National Bureau of Standards on the "Analysis, Purification, and Properties of Hydrocarbons".

"Analysis, Purification, and Properties of Hydrocarbons". nate those mixtures of branched-chain paraffin hydrocarbons produced by the addition of paraffins to olefins.

${ }_{3}$ A. R. Glasgow, Jr., A. J. Streiff, C. B. Willingham, and F. D. Rossini, Proc. Am. Petroleum Inst. 26 (III), 127 (1946); J. Research NBS 38, 537 (1947) RP1795.
}

of butenes, in a tubular type reactor with phosphoric acid as the catalyst (the process of the Universal Oil Products Co.). The samples are listed according to the American Petroleum Institute Research Project 6 numbers. Samples numbers 38 and 39 were prepared at the Bayway Laboratories of the Standard Oil Co. of New Jersey as Bayway test runs 11 and 12 , respectively. Codimer sample number 45 and hydrocodimer sample number 44 were prepared at the Heysham Refinery of Trimpel Limited, London, Eng., and had the designation HSO 1685 and HSO 1684, respectively. The analysis of hydrocodimer sample number 44 , which was the hydro-

TABLE 1. Operating conditions and product inspections for samples analyzed

\begin{tabular}{|c|c|c|c|}
\hline APIRP-6 sample & 38 & 39 & 45 \\
\hline $\begin{array}{l}\text { Source } \\
\text { Catalyst } \\
\text { Process } \\
\text { Reactor type }\end{array}$ & $\begin{array}{l}\text { S. O. N. J. } \\
\text { Phosphoric } \\
\text { acid } \\
\text { U. O.P. } \\
\text { Tubular }\end{array}$ & $\begin{array}{l}\text { S. O. N. J. } \\
\text { Phosphoric } \\
\text { acid } \\
\text { U.O.P. } \\
\text { Tubular }\end{array}$ & $\begin{array}{l}\text { Trimpel } \\
\text { Phosphoric } \\
\text { acid } \\
\text { U.O.P. } \\
\text { Tubular }\end{array}$ \\
\hline $\begin{array}{l}\text { Fresh feed, butene/dimer } \\
\text { Fresh feed analysis, percent by } \\
\text { volume: } \\
\quad \mathrm{C}_{3} \mathrm{H}_{6} \\
\quad \mathrm{\textrm {C } _ { 4 }} \mathrm{H}_{8} \\
n \mathrm{C}_{4} \mathrm{H}_{8} \\
\mathrm{C}_{5} \mathrm{H}_{10}\end{array}$ & $\begin{array}{r}7950 \\
\\
0.4 \\
13.4 \\
25.9 \\
2.1\end{array}$ & $\begin{array}{r}0.3 \\
12.9 \\
26.4 \\
0.5\end{array}$ & $\begin{array}{r}1.0 \\
17.0 \\
7.2 \\
0\end{array}$ \\
\hline $\begin{array}{l}\text { Recycle ratio } \\
\text { Space velocity }\end{array}$ & $\begin{array}{r}0.07 \\
.82\end{array}$ & $\begin{array}{l}0 \\
0.87\end{array}$ & $\begin{array}{l}0 \\
0.72\end{array}$ \\
\hline $\begin{array}{l}\text { Temperature inlet, }{ }^{\circ} \mathrm{F} \\
\text { Temperature outlet, }{ }^{\circ} \mathrm{F} \\
\text { Pressure, lb/in. }\end{array}$ & $\begin{array}{l}283 \\
303 \\
600\end{array}$ & $\begin{array}{l}373 \\
413 \\
847\end{array}$ & $\begin{array}{l}308 \\
324 \\
800\end{array}$ \\
\hline $\begin{array}{l}\text { Olefin conversion, percent by } \\
\text { volume } \\
\text { Reaction ratio a }\end{array}$ & $\begin{array}{c}52.5 \\
1.72\end{array}$ & $\begin{array}{c}76.0 \\
2.22\end{array}$ & $\begin{array}{c}92.8 \\
1.41\end{array}$ \\
\hline $\begin{array}{l}\text { Contribution to polymer based on } \\
\text { disappearance of olefin gas, per- } \\
\text { cent by volume: } \\
\mathrm{C}_{3} \mathrm{H}_{6} \\
\text { i } \mathrm{C}_{4} \mathrm{H}_{8} \\
n \mathrm{C}_{4} \mathrm{H}_{8} \\
\mathrm{C}_{5} \mathrm{H}_{10}\end{array}$ & $\begin{array}{r}1 \\
58 \\
38 \\
3\end{array}$ & $\begin{array}{r}1 \\
45 \\
53 \\
1\end{array}$ & $\begin{array}{r}4 \\
71 \\
25 \\
0\end{array}$ \\
\hline $\begin{array}{l}\text { Inspections, ASTM octane number: } \\
\text { Without addition of TEL } \\
\text { F-3 with addition of } 4 \mathrm{ml} \text { of } \\
\text { TEL per gallon } \\
\text { F-4 with addition of } 4 \mathrm{ml} \text { of } \\
\text { TEL per gallon. }\end{array}$ & $\begin{array}{r}96.3 \\
108.0 \\
\text { b } 172\end{array}$ & $\begin{array}{r}88.2 \\
103.2 \\
\text { b } 144\end{array}$ & . \\
\hline
\end{tabular}

a Reaction ratio $=$ total olefins converted/isobutylene converted. b Blending value. 
genated product of codimer sample number 45 , was previously reported (see footnote 3 ).

The pertinent operating conditions and inspection data on the samples, submitted by the above companies, are given in table 1 . The analyses of the olefins in the fresh feed to the reactor and in the debutanized overhead from the reactor, expressed as the disappearance of olefin gas in table 1 , give a measure of the components reacting in the process. The large decrease in the butene content shows that the predominant reaction is between the butenes.

\section{Method of Analysis and Results}

The analyses were made by utilizing distillations performed at high efficiency with high reflux ratio, with accurately measured values of the boiling point (to $\pm 0.01 \mathrm{deg} \mathrm{C}$ ) and of the refractive index (to $\pm 0.0001)$ of the fractions of distillate, and with separation by adsorption of the paraffin portion of selected distillate.

In preparation for the analytical distillations, the bulk of the peroxides was removed from the samples of codimer by simple distillation in vacuum, with the distilling temperature near or slightly below room temperature and the temperature of the receiver about $-78^{\circ} \mathrm{C}$. Hydroquinone was added to the pot and the receiver to serve as an antioxidant. The bulk of the peroxides was contained in the undistilled portions, which were withheld from further analysis. These residues, expressed as percentage of the volume distilled, were for samples 38, 39, and 45 about 10,10 , and 1 percent, respectively. The distillates, after the addition of $25 \mathrm{~g}$ of hydroquinone to each, were subjected to analytical distillations, the details of which are given in table 2. Complete details regarding the distilling operations are given in a paper by Willingham and Rossini. ${ }^{4}$

TABLE 2. Information on the analytical distillation of three codimers

\begin{tabular}{|c|c|c|c|c|c|c|c|c|c|}
\hline \multirow[b]{2}{*}{$\begin{array}{l}\text { Sample } \\
\text { number }\end{array}$} & \multirow[b]{2}{*}{ Material } & \multicolumn{8}{|c|}{ Distillation } \\
\hline & & $\begin{array}{l}\text { Distilling } \\
\text { column } \\
\text { number }\end{array}$ & $\begin{array}{l}\text { Number of equiv- } \\
\text { alent theoretical } \\
\text { plates at } \\
\text { total reflux } \\
\text { (approximately) }\end{array}$ & $\begin{array}{l}\text { Reflux ratio } \\
\text { (approxi- } \\
\text { mately) }\end{array}$ & $\begin{array}{l}\text { Rate of } \\
\text { collection } \\
\text { of distillate }\end{array}$ & $\begin{array}{l}\text { Volume of } \\
\text { charge }\end{array}$ & $\begin{array}{c}\text { Volume of } \\
\text { each } \\
\text { fraction }\end{array}$ & $\begin{array}{l}\text { Results } \\
\text { plotted in } \\
\text { figure- }\end{array}$ & $\begin{array}{l}\text { Analysis } \\
\text { given in } \\
\text { table- }\end{array}$ \\
\hline $\begin{array}{l}38 \\
39 \\
45\end{array}$ & $\begin{array}{l}\text { Codimer, TAC, Bayway } 11 \\
\text { Codimer, TAC, Bayway } 12 \\
\text { Codimer, HSO-1685 }\end{array}$ & $\begin{array}{r}\text { no. } \\
2 \\
3 \\
4\end{array}$ & $\begin{array}{l}100 \\
100 \\
200\end{array}$ & $\begin{array}{l}150 / 1 \\
150 / 1 \\
165 / 1\end{array}$ & $\begin{array}{r}m l / h r \\
2.0 \\
2.0 \\
4.5\end{array}$ & $\begin{array}{l}m l \\
4,500 \\
3,600 \\
4,975\end{array}$ & \begin{tabular}{r}
\multicolumn{1}{l}{$m l$} \\
8.2 \\
7.5 \\
16.7
\end{tabular} & $\begin{array}{l}2 \\
1 \\
3\end{array}$ & $\begin{array}{l}3 \\
3 \\
3\end{array}$ \\
\hline
\end{tabular}

Changes in composition of the distillate from the analytical distillations caused by oxidation, polymerization, etc. of the component olefins, were minimized by storage of the distillate at $8^{\circ}$ to $10^{\circ} \mathrm{C}$ in amber glass bottles with screw caps. To determine the magnitude of any changes in composition, measurements of the refractive indices of the distillate from codimer sample 39 were made as follows: (a) Within 1 to 2 days after collection from the distilling column with storage at $8^{\circ}$ to $10^{\circ} \mathrm{C}$; (b) after 6 weeks of storage at $8^{\circ}$ to $10^{\circ} \mathrm{C}$; and (c) after 6 weeks of additional storage at room temperature (near $25^{\circ} \mathrm{C}$ ). These data are given in figure 1 . The results given in the figure as the two solid lines of refractive index, for conditions (a) and (b) above, show that under refrigerated conditions the refractive index remained substantially constant. However, after 6 weeks of storage at room temperature, changes in the refractive index of the material occurred, as shown by the broken line. These data on refractive index show that in the analysis of material of this kind it is necessary to refrigerate the fractions of distillate and to determine the necessary properties without delay.

Reduction of the data from a large-scale plot of the boiling point and the refractive index of the distillate as a function of the volume of the distillate, to obtain the amounts of the individual components, was made in the same manner as that previously described for the analysis of the paraffin mixtures of alkylates and hydrocodimers (see footnote 3 ). In calculations for sample number 45 , use was made of the results of the analysis of the corresponding hydrocodimer under the assumption that the process of hydrogenating the codimer to form the hydrocodimer did not alter the carbon skeleton of any significant number of molecules. This assumption appears to be substantially correct since it served to produce a logical correlation among the amounts of the components of the respective mixtures, as shown in table 4 . Furthermore, to simplify the analysis of codimer sample number 45 , the presence of 2,2-dimethylhexane (0.9 percent) in the hydrocodimer and corresponding olefins in the codimer was ignored.

Upon inspection of the data, it was evident that paraffin impurities were present in the codimers For example, in codimer number 38 , as shown in figure 2 , a flat occurs in the boiling point curve at the boiling point of $n$-pentane. Moreover, the corresponding index of refraction is lower $\left(N_{\mathrm{D}}\right.$ at $25^{\circ} \mathrm{C}$, 1.3623) than would be expected for any olefins boiling in this region, although higher than the refractive index of pure $n$-pentane (1.3547). Therefore, recourse was made to filtration through silica gel, to separate any $n$-pentane from the olefins. After passage of a 1-ml portion of this distillate through silica gel ${ }^{5}$ the first few drops of filtrate had refractive indices increasing successively from 1.3531 to 1.3546 .

${ }^{5}$ A. R. Glasgow, Jr., C. B. Willingham, and F. D. Rossini, Ind. Eng. Chem. 41, 2292 (1949). 


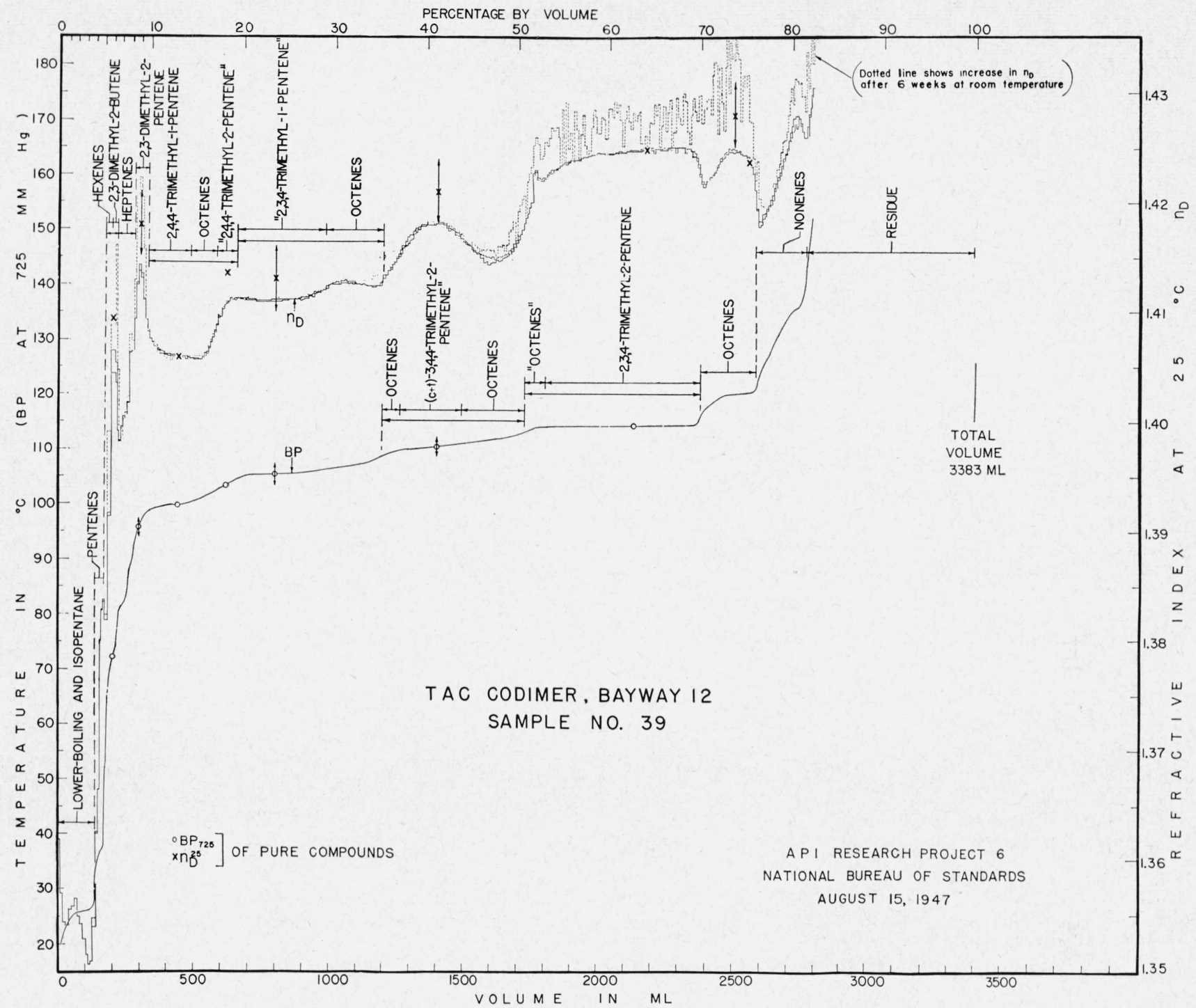

Figure 1. Results of the analytical distillation of codimer sample number 39.

The uncertainties in the values of the refrective index and boiling point for the pure components are indicated by the limits of the arrowed line drawn through

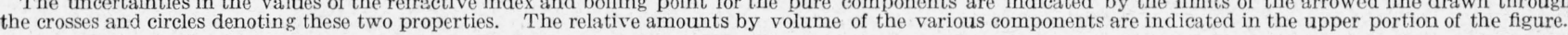

The adsorbed portion, after displacement by ethanol, was found to have the refractive index 1.3757 , indicating that the material boiling in the flat was largely $n$-pentane with some isopentane $\left(N_{\mathrm{D}}\right.$ at $\left.25^{\circ} \mathrm{C}, 1.3509\right)$ and some olefin.

Similarly, the refractive index curve for codimer number 45 indicated the presence of paraffin hydrocarbons. Therefore, $10-\mathrm{ml}$ portions of fractions of the distillate that appeared to contain paraffin hydrocarbons (A, B, C, and D in fig. 3) were filtered through a column of silica gel (28 to 200 mesh, about $1 \mathrm{~cm}$ in diameter and $50 \mathrm{~cm}$ in length). One milliliter of the first portion of filtrate was then passed through a small column (see footnote 5). The refractive indices of the paraffin portions and the components of the mixtures, as deduced from the boiling point together with the refractive index $\left(N_{\mathrm{D}}\right.$ at $\left.25^{\circ} \mathrm{C}\right)$, were as follows: $\mathrm{A}, 1.3798,2,2$ - and 2,4-dimethylpentane; B, 1.3896, 2,3-dimethylpentane; C, 1.3890, 2,2,4-trimethylpentane; and D, 1.4025 , 2,3,4-trimethylpentane plus some 2,3,3-trimethylpentane. The amount of 2,2,4-trimethylpentane in sample number 45 and its apparent absence in samples 38 and 39 , as indicated by the boiling point and refractive index curves, are shown in figure 4. The circles and crosses in the figure refer to the boiling point and refractive index, respectively, of the pure compounds. The volume of each of the components in the distillates, based on the reduction of the boiling point and refractive 


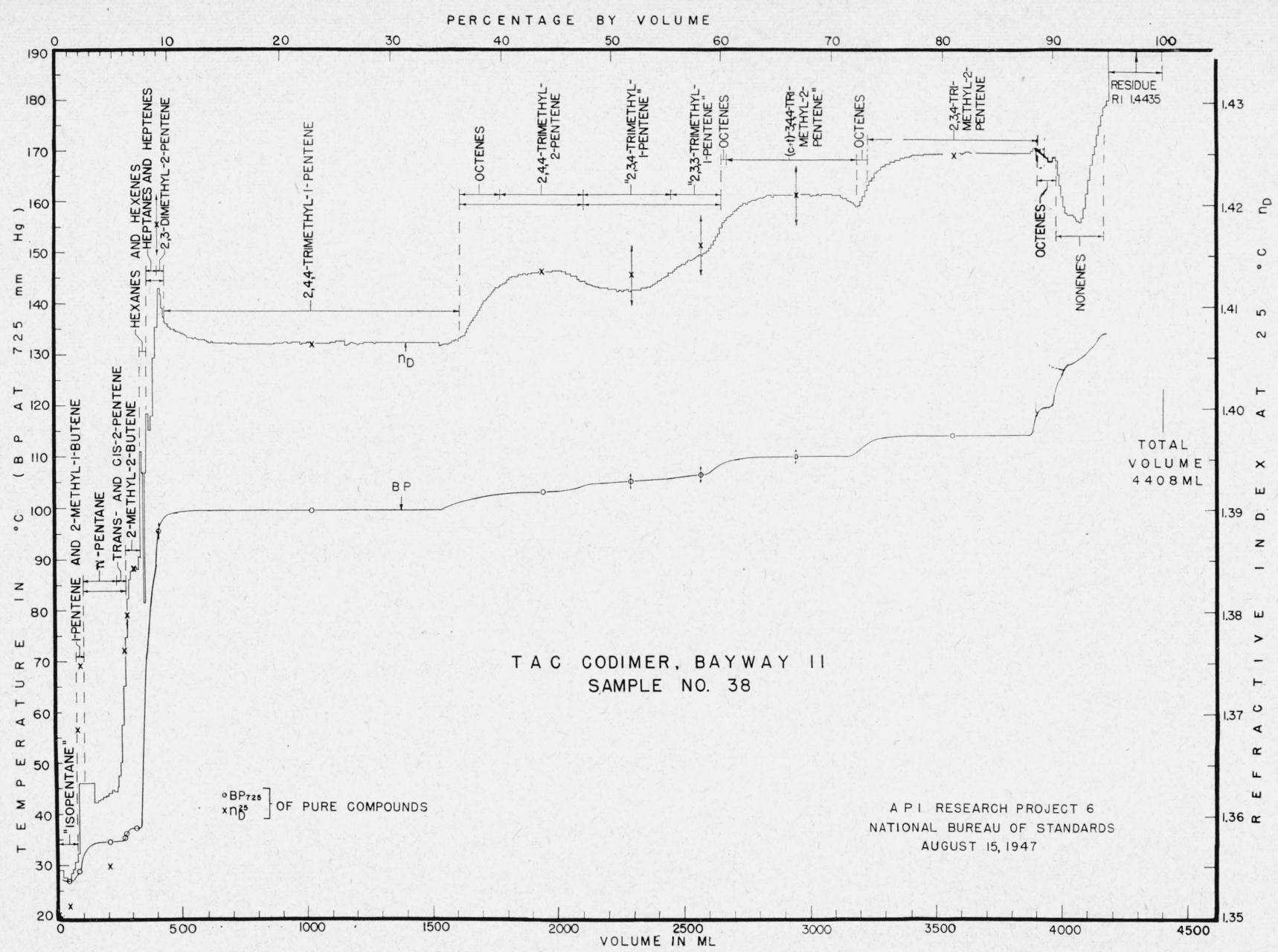

Figure 2. Results of the analytical distillation of codimer sample number 38 .

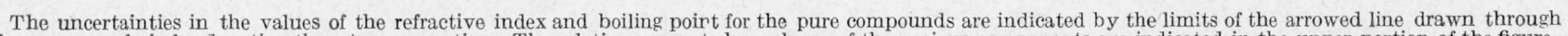

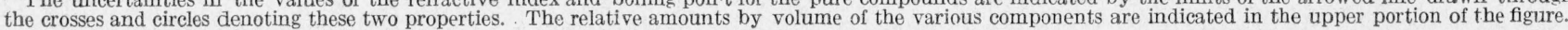




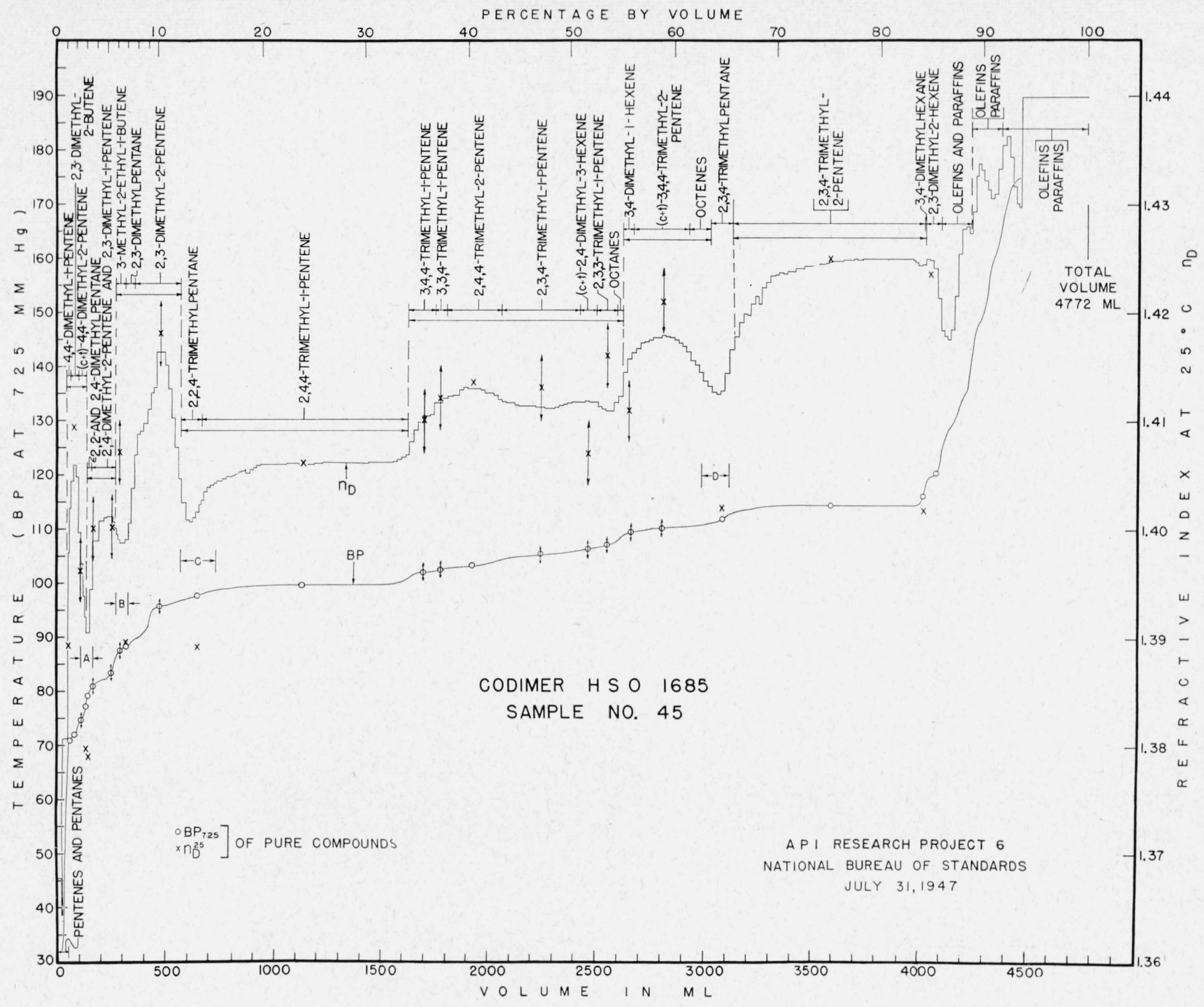

Figure 3. Results of the analytical distillation of codimer sample number 45 .

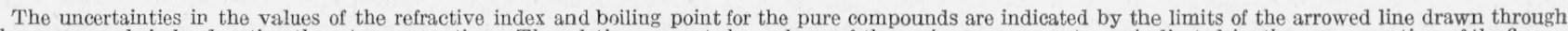

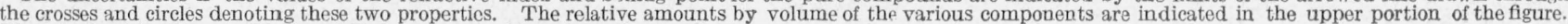
The blends of distillate A, B, C, and D were processed by adsorption, see text. 


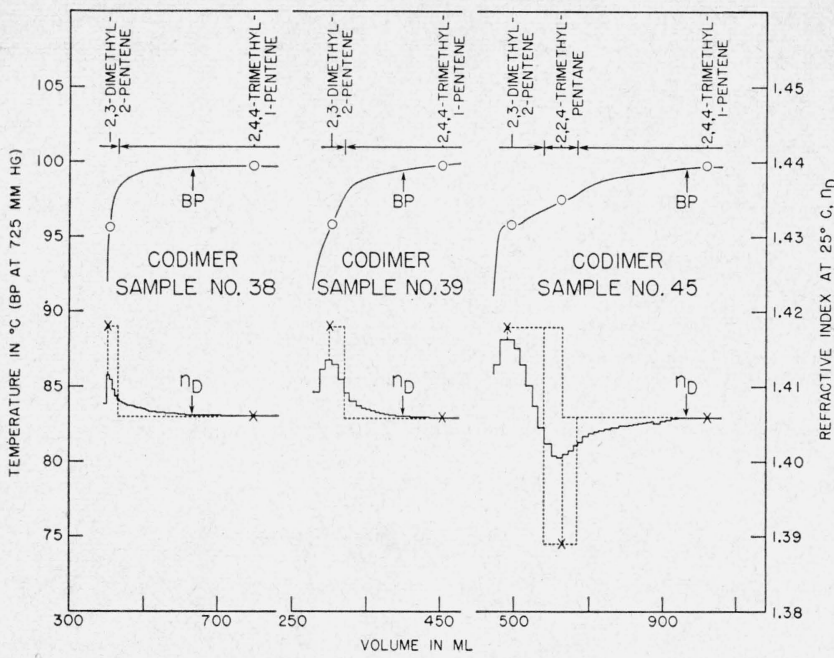

Figure 4. Comparison of distillate from codimers in the region of the boiling point of 2,2,4-trimethylpentane.

index data, is indicated in the upper portion of the figure. The broken lines accompanying the refractive index curves indicate the division into components, as deduced from the above properties.

The results for codimer samples 38,39 , and 45 are given in figures 1,2 , and 3 and in table 3 . The material boiling below pentanes and pentenes, which constituted 7.5 and 5.0 percent of the total volume distilled for samples 38 and 39, respectively, had the following composition expressed as percentage of the total volume distilled:

Sample number 38 , isopentane plus lower-boiling material, $1.7 \pm 0.4 ; 1$-pentene plus 2 -methyl-1-butene, $0.6 \pm 0.4 ; n$-pentane, $3.1 \pm 0.8 ;$ cis-plus trans-2pentene, $0.8 \pm 0.3 ; 2$-methyl-2-butene, $1.3 \pm 0.3$.

Sample number 39, isopentane plus lower-boiling hydrocarbons, $4.0 \pm 0.3$; pentenes plus $n$-pentane, $1.0 \pm 0.5$.

From the analyses given in table 3 , the relative amounts by volume of the trimethylpentenes in the codimers that would yield the same trimethylpentane on hydrogenation without alteration in the carbon skeleton were as follows:

(a) 2,4,4-trimethyl-1-pentene, 2 to 4 times that of 2,4,4-trimethyl-2-pentene; (b) 2,3,4-trimethyl-2-pentene, about two times that of 2,3,4-trimethyl-1pentene; (c) 3,4,4-trimethyl-2-pentene, two to three times that of 3,3,4-trimethyl-1-pentene; and (d) 2,3,3-trimethyl-1-pentene, slightly greater than 3,3,4trimethyl-1-pentene.

Figure 5 shows the distribution of olefins in the $\mathrm{C}_{8}$ portion of hydrocodimer, sample number 44 .

The open and solid circles give the boiling points of the pure paraffins and olefins, respectively, and the crosses refer to the values of the refractive indices of the pure compounds. The refractive index of the original distillate containing olefins is given by the broken line and that of the paraffin portion, by the solid line. The difference in the refractive index of the paraffin portion and that of the original distillate is shown in the lower portion of the figure. The areas obtained by plotting the increase in refractive index due to olefins as a function of the volume of distillate, together with the corresponding plot of

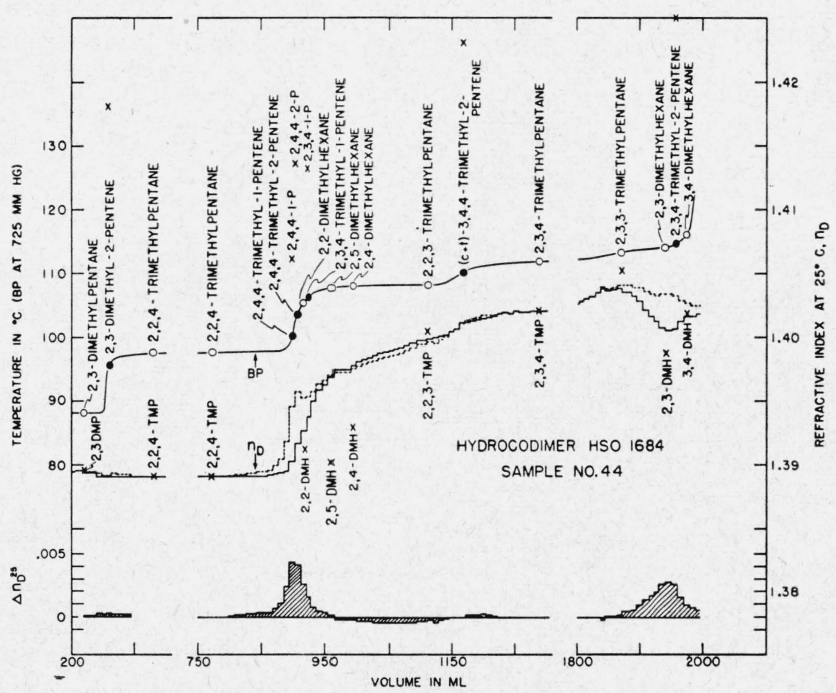

Figure 5. Distribution of olefins in the $\mathrm{C}_{8}$ portion of hydrocodimer sample number 44.

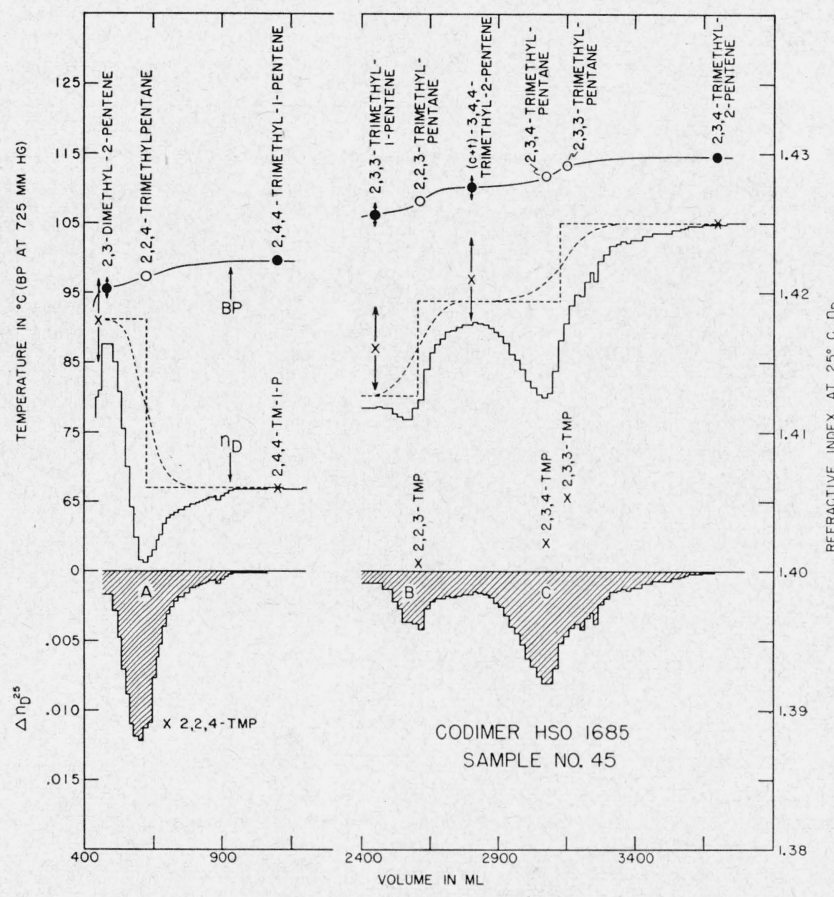

Figure 6. Distribution of major $\mathrm{C}_{8}$ paraffins in the $\mathrm{C}_{8}$ portion of codimer sample number 45 . 
TABLE 3. Components of material boiling above pentanes and pentenes

\begin{tabular}{|c|c|c|c|c|c|c|c|}
\hline \multirow{2}{*}{ Components } & \multirow{2}{*}{$\begin{array}{l}\text { Boiling point } \\
\text { at } 1 \mathrm{~atm}\end{array}$} & \multicolumn{2}{|c|}{$\begin{array}{c}\text { Codimer } \\
\text { Sample No. } 38\end{array}$} & \multicolumn{2}{|c|}{$\begin{array}{c}\text { Codimer } \\
\text { Sample No. } 39\end{array}$} & \multicolumn{2}{|c|}{$\begin{array}{c}\text { Codimer } \\
\text { Sample No. } 45\end{array}$} \\
\hline & & \multicolumn{6}{|c|}{ Percentage by volume (above $\mathrm{C}_{5}$ components) } \\
\hline $\begin{array}{l}\text { 4,4-Dimethyl-1-pentene } \\
\text { 2,3-Dimethyl-2-butene } \\
\text { 4,4-Dimethyl-2-pentene a } \\
\text { Hexenes } \\
\text { Hexenes b }+ \text { hexanes. }\end{array}$ & $\begin{array}{l}\quad{ }^{\circ} \mathrm{C} \\
72.2 \\
73.2 \\
76 \\
41 \text { to } 70 \\
49 \text { to } 73\end{array}$ & $0.7 \pm 0.3$ & $0.7 \pm 0.3$ & $\begin{array}{c}0.7 \pm 0.4 \\
0.7 \pm 0.4 \\
0\end{array}$ & $1.4 \pm 0.4$ & $\left.\begin{array}{r}0.4 \pm 0.2 \\
.7 \pm .3 \\
.9 \pm .5 \\
\hdashline\end{array}\right\}$ & $2.0 \pm 0.5$ \\
\hline $\begin{array}{l}\text { 2,2-Dimethylpentane } \\
\text { 2,4-Dimethylpentane... } \\
\text { 2,4-Dimethyl-2-pentene } \\
\text { 2,3-Dimethyl-1-pentene } \\
\text { 3-Methyl-2-ethyl-butene.... } \\
\text { 2,3-Dimethylpentane } \\
\text { Heptenes } \\
\text { 2,3-Dimethyl-2-pentene }\end{array}$ & $\begin{array}{l}79.2 \\
80.5 \\
82.4 \\
85 \\
89 \\
89.8 \\
76 \text { to } 95 \\
97\end{array}$ & $\begin{array}{l}0.3 \\
1.0 \pm 0.3 \\
0.8 \pm .3\end{array}$ & $1.8 \pm 0.3$ & $\left.\begin{array}{l}0.7 \\
2.0 \pm 0.7 \\
1.6 \pm .7\end{array}\right\}$ & $3.6 \pm 0.7$ & $\begin{array}{l}0.4 \pm 0.2 \\
2.3 \pm 0.7 \\
1.0 \pm 0.5 \\
0.8 \pm 0.4 \\
4.4 \pm 1.5\end{array}$ & $8.9 \pm 1.0$ \\
\hline $\begin{array}{l}\text { 2,2,4-Trimethylpentane } \\
\text { 2,4,4-Trimethyl-1-pentene }\end{array}$ & $\begin{array}{r}99.2 \\
101.4\end{array}$ & $28.6 \pm 1.3$ & $28.6 \pm 1.3$ & $4.9 \pm 0.7$ & $4.9 \pm 0.7$ & $\begin{array}{r}2.1 \pm 0.7 \\
20.4 \pm 1.0\end{array}$ & $22.5 \pm 1.0$ \\
\hline $\begin{array}{l}\text { Octenes } \\
\text { 3,4,4-Trimethyl-1-pentene } \\
\text { 3,3,4-Trimethyl-1-pentene. } \\
\text { 2,4,4-Trimethyl-2-pentene }\end{array}$ & $\begin{array}{l}102 \text { to } 104 \\
104 \\
105 \\
104.9\end{array}$ & $\left.\begin{array}{c}3.9 \pm 1.3 \\
7.8 \pm 1.6\end{array}\right\}$ & $11.7 \pm 1.5$ & $\left.\begin{array}{c}3.1 \pm 0.9 \\
\hdashline 2.1 \pm 0.9\end{array}\right\}$ & $5.2 \pm 0.9$ & $\begin{array}{r}\text { g } 2.6 \pm 1.0 \\
1.2 \pm 0.6 \\
5.4 \pm 1.5\end{array}$ & $9.2 \pm 1.2$ \\
\hline $\begin{array}{l}\text { 2,3,4-Trimethyl-1-pentene } \\
\text { 2,4-Dimethyl-3-hexene }{ }^{\mathrm{a}} \\
\text { 2,3,3-Trimethyl-1-pentene. } \\
\text { Octenes } \\
\text { Octanes }{ }^{\mathrm{f}} \\
\text { 3,4-Dimethyl-1-hexene } \\
\text { 3,4,4-Trimethyl-2-pentene } \\
\text { Octenes } \mathrm{h}\end{array}$ & $\begin{array}{l}108 \\
108 \\
108.4 \\
108 \text { to } 112 \\
109 \text { to } 110 \\
112 \\
112 \\
110 \text { to } 112.5\end{array}$ & $\left.\begin{array}{r}8.5 \pm 3.0 \\
0.5 \pm 0.3 \\
012.7 \pm 1.7 \\
\hdashline-1.3\end{array}\right\}$ & $26.6 \pm 2.0$ & $\left.\begin{array}{c}{ }^{\circ} 10.3 \pm 1.1 \\
8.8 \pm 1.5 \\
\hdashline 7.2 \pm 3.6\end{array}\right\}$ & $26.3 \pm 2.0$ & $\begin{array}{l}7.8 \pm 2.0 \\
1.7 \pm 0.8 \\
1.9 \pm 0.9 \\
0.5 \pm 0.2 \\
1.1 \pm 0.8 \\
5.4 \pm 1.7 \\
2.0 \pm 1.0\end{array}$ & $20.4 \pm 1.5$ \\
\hline $\begin{array}{l}\text { Octenes } \\
\text { Octenes } \\
\text { 2,3,4-Trimethyl-2-pentene } \mathrm{j} \\
\text { 2,3,4-Trimethylpentane } \mathrm{j}\end{array}$ & $\begin{array}{l}112 \text { to } 115 \\
115 \text { to } 116 \\
116.3 \\
113.5\end{array}$ & $\left\{\begin{array}{c}\text { e } 1.0 \pm 0.6 \\
16.6 \pm 0.6\end{array}\right.$ & $17.6 \pm 0.6$ & $\begin{array}{r}7.2 \pm 2.0 \\
2.4 \pm 1.5 \\
18.0 \pm 1.5 \\
\end{array}$ & $27.6 \pm 2.0$ & $\begin{array}{r}18.9 \pm 1.5 \\
2.2 \pm 1.0\end{array}$ & $21.1 \pm 1.5$ \\
\hline $\begin{array}{l}\text { 3,4-Dimethylhexane } \\
\text { 2,3-Dimethyl-2-hexene } \mathrm{k}^{\mathrm{d}} \\
\text { Octenes } \mathrm{d}\end{array}$ & $\begin{array}{l}117.3 \\
122.1 \\
117 \text { to } 123\end{array}$ & $1.9 \pm 0.4\}$ & $1.9 \pm 0.4$ & $6.4 \pm 0.6$ & $6.4 \pm 0.6$ & $\begin{array}{l}0.1 \pm 0.05 \\
1.6 \pm 0.7\end{array}$ & $1.7 \pm 0.7$ \\
\hline 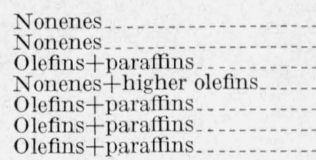 & $\begin{array}{l}124 \text { to } 136 \\
124 \text { to } 149 \\
123 \text { to } 141 \\
>136 \\
>149 \\
141 \text { to } 165 \\
>165\end{array}$ & $\left.\begin{array}{c}4.6 \pm 0.3 \\
\hdashline 6.5 \pm 0.3 \\
\hdashline\end{array}\right\}$ & $11.1 \pm 0.3$ & $\begin{array}{l}5.8 \pm 0.5 \\
19.0 \pm 0.4 \\
-\end{array}$ & $24.8 \pm 0.5$ & $\left.\begin{array}{c}2.9 \pm 0.7 \\
2.9 \pm 0.7 \\
8.4 \pm 0.5\end{array}\right\}$ & $14.2 \pm 0.7$ \\
\hline Total_ & & - & 100.0 & $\ldots$ & 100.0 & & 100.0 \\
\hline
\end{tabular}

a $C t s$ and trans isomers.

b May contain some 4,4-dimethyl-1-pentene (a heptene).

- May include other octenes.

d May include some nonenes.

e May include some octanes.

f Includes 2,2,3-trimethylpentane, 2,5-dimethylhexane, and 2,4-dimethylhexane.

g Ma in 3 , 3 -methyl-2-isopropyl-1-butene near $104^{\circ} \mathrm{C}$

h These octenes may include 3,3-dimethyl-2-ethyl-1-butene, 2,4-dimethyl-2-hexene, 4-methyl-2-ethyl-1-pentene, 2,4-dimethyl-1-hexene, 2,5-dimethyl-1-hexene, $(c+t)$-3,5-dimethyl-2-hexene, 2,5-dimethyl-2-hexene, and 3-methyl-2-ethyl-1-pentene.

includes small amount of 2,3,3-trimethylpentane and 2,3-dimethylhexane.

j May include some $(c+t)$-3,4-dimethyl-2-hexene.

k May include some 3,4-dimethyl-3-hexene.

boiling point versus volume, show the distribution of the olefins in the distillate of the $\mathrm{C}_{8}$ paraffins.

Figure 6 shows the distribution of major $\mathrm{C}_{8}$ paraffins in the $\mathrm{C}_{8}$ portion of codimer sample number 45 and the method used in deducing this distribution. In figure 6 the open and solid circles give the boiling points of the pure paraffins and olefins, respectively, and the crosses refer to the values of the refractive indices of the pure compounds. The uncertainty in each of these values is indicated by the limits of the arrowed line drawn through the property. The broken curves accompanying the observed refractive indices (solid lines) are the curves calculated for the separation that would have been obtained in the distilling column if no paraffins had been present in the material. The blocked broken lines were for the same condition with perfect separation, and were used to calculate the shapes of the broken curves. The lowering in refractive index due to paraffin was then calculated as the difference between the broken curve and the observed refractive index. The areas $\mathrm{A}, \mathrm{B}$, and $\mathrm{C}$ obtained by plotting the decrease in refractive index due to paraffin as a function of the volume of distillate, together with the corresponding plot of boiling point versus volume, show the distribution of the major $\mathrm{C}_{8}$ paraffins in the distillate to be as follows: A, 2,2,4-trimethylpentane; B, 2,2,3trimethylpentane; C, 2,3,4-trimethylpentane plus 2,3,3-trimethylpentane.

Figures 5 and 6 also show that no significant number of molecules underwent alteration in their carbon skeletons during hydrogenation of the codimer to form the hydrocodimer. That is, the predominant $\mathrm{C}_{8}$ olefins present as impurity in the 
hydrocodimer have the same carbon skeleton as the predominant paraffins, and similarly the predominant $\mathrm{C}_{8}$ paraffins present as impurity in the codimer have the same carbon skeleton as the predominant olefins.

Table 4 is the correlation of the olefins found in codimer sample number 45 with the paraffins of the same carbon skeleton in the corresponding hydrocodimer (sample number 44) for the material boiling above pentanes and pentenes. The material boiling below pentanes and pentenes was 0.8 and 0.2 percent of the total volume distilled for the codimer and hydrocodimer, respectively.

Grateful acknowledgment is made to Frederick D. Rossini for his many suggestions in the course of the investigation and in the preparation of this report, to Charles B. Willingham for supervising the distillations, and to Morton B. Epstein for assisting in the analytical reduction of the data as described (see footnote 3).

TABLE 4. Correlation of the olefins in the codimer with paraffins of the same carbon skeleton in the corresponding hydrocodimer for the material boiling above pentanes and pentenes

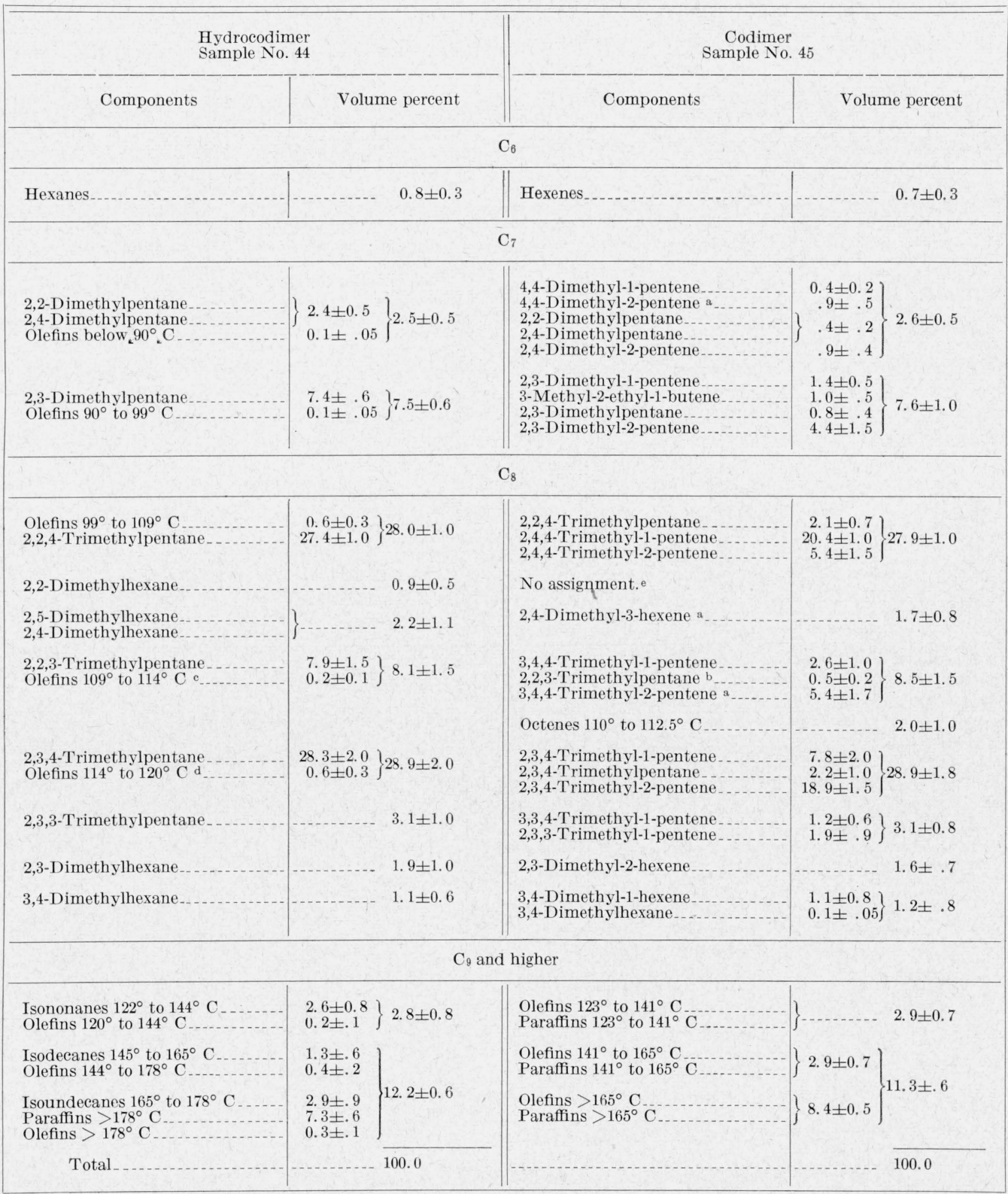

a Cis and trans isomers.

b May include smaller amount of 2,5-dimethylhexane and 2,4-dimethylhexane.

. The predominant olefin in this boiling range is 3,4,4-trimethyl-2-pentene, which is grouped with 2,3,3,-trimethylpentane.

$\mathrm{d}$ The predominant olefin in this boiling range is 2,3,4-trimethyl-2-pentene, which is grouped with 2,3,4-trimethylpentane.

e The five olefin isomers of the same carbon skeleton as 2,2-dimethylhexane normally boiling in the region $101^{\circ}$ to $107^{\circ} \mathrm{C}$ close to large concentrations of other isomers made impracticable any direct assignment of the 0.9 percent of this isomer in the codimer.

Washington, October 2, 1950. 